\title{
Psychology and the Aims of Normative Ethics
}

\author{
Regina A. Rini \\ University of Oxford \\ regina.rini@philosophy.ox.ac.uk
}

\begin{abstract}
This chapter discusses the philosophical relevance of empirical research on moral cognition. It distinguishes three central aims of normative ethical theory: understanding the nature of moral agency, identifying morally right actions, and determining the justification of moral beliefs. For each of these aims, the chapter considers and rejects arguments against employing cognitive scientific research in normative inquiry. It concludes by suggesting that, whichever of the central aims one begins from, normative ethics is improved by engaging with the science of moral cognition.
\end{abstract}

Key words: is/ought gap, moral agency, moral intuition, moral philosophy, ought-impliescan

\section{Three Central Questions of Normative Ethics}

It is undeniable that the field of empirical moral psychology has grown dramatically in the last decade, with new experimental techniques allowing us unprecedented understanding of the causal and computational structures of the human moral faculty. Or, at least, it is undeniable that this research contributes to a descriptive project, one of better understanding the facts about who we are and how we think. ${ }^{1}$ But what might be denied is that these investigations have much to offer to normative ethics, a distinctively prescriptive sort of inquiry. ${ }^{2}$ The purpose of this chapter is to show why normative ethics - the study of

\footnotetext{
${ }^{1}$ Although this chapter discusses quite a range of psychological findings, it is not intended to be a comprehensive overview of the empirical literature. For more, see (Doris \& Stich 2007), (Appiah 2008), (Levy 2009), and (Knobe 2010).

${ }^{2}$ There is one sense in which no one doubts the relevance of empirical findings to normative ethics. That is in applying settled normative views to actual circumstances. Obviously psychology - and ordinary daily experience - can aid us in learning how to bring about the moral goals we have set, once those goals are already determined. What is at issue in this chapter is something different: can empirical moral psychology play a role in helping to determine what the moral goals themselves ought to be?
} 
how we ought to live our lives and what we ought to value - can indeed benefit from engagement with empirical moral psychology. ${ }^{3}$

We ought to begin with some conception of what normative ethics is and how the inquiry operates. Unfortunately, there is nothing like consensus on those matters among ethicists. I will therefore adopt a piecemeal dialectical strategy, setting out different ways we might characterize the discipline, and then asking of each one in turn how empirical moral psychology might be brought to bear.

I suggest that each of the following is a central question of normative ethics:

1. What is it to be a moral agent?

2. Which actions are morally permitted or required?

3. Which of our moral beliefs are justified?

These questions are not necessarily rivals; one could certainly hold that normative ethics aims at addressing all of these questions. Some philosophers do see one of these questions as conceptually prior to the others, or indeed see one as exhaustively constituting the subject matter of normative ethics, but I will not be engaging with such disputes here.

Each of the following sections discusses one of these questions, and each section follows a common structure. First I discuss a negative argument, one claiming that answering the target central question allows little relevance for empirical moral psychology. Then I offer a reply, arguing that further reflection on the central question instead favours a more welcoming conclusion for empirical moral psychology. Finally I provide illustrative examples of relevant empirical research. The point of this structure is partly expository, since the chapter aims to provide an overview of many branches of a growing debate. But there is also a dialectical strategy here: if it can be shown that, whichever of the three central questions one begins from, negative arguments can be reversed into positive arguments, then the relevance of empirical moral psychology should be convincingly secured.

\section{What is it to be a moral agent?}

\section{II.1 Challenge: Rational Agency and the Practical Perspective}

Most healthy adult human beings are moral agents, capable of engaging with moral reasons and being held morally responsible for their actions. But what constitutes a moral

\footnotetext{
${ }^{3}$ Some clarification about terms: by 'empirical moral psychology' I mean to be ecumenical, encompassing research by psychologists, neuroscientists, biologists, behavioral economists, sociologists, and experimental philosophers. By 'normative ethics' I mean the branch of moral philosophy concerned with how we ought to live our lives, what things we ought to value, and what practical decisions we ought to make. I will not be discussing certain related topics, such as free will and moral responsibility, or naturalistic moral ontology.
} 
agent? Many philosophers have thought that answering this question is central to normative ethics, in that providing an answer would subsequently guide theory about how to live our lives. I begin this section by sketching one very influential answer - one which appears to have the consequence of rendering empirical psychology irrelevant to normative ethics.

The Enlightenment philosopher Immanuel Kant claimed that basic elements of normative ethics (such as his famous categorical imperative) follow directly from a conception of moral agency as grounded in rational nature. ${ }^{4}$ According to Kant, taking moral decisions seriously requires thinking of ourselves as rational beings, as beings who can determine for ourselves the rules that govern our actions, rather than being determined by the laws of nature that govern everything else. When we take up the question of how we should live our lives, it makes no sense to think of ourselves in terms of natural laws. Asking what we should do presupposes that we have some say in the matter, whereas an investigation of natural laws aims at showing what must happen. So for Kant, moral inquiry is fundamentally practical, in that it is conducted from an orientation aimed at guiding genuine choices, and not simply at describing the world.

Clearly, on this conception of moral agency, there will be difficulties employing empirical moral psychology in normative ethics. Psychology concerns itself with the causal structure of our thought; in Kant's terms, it aims at describing the natural laws that govern how we think. But describing causal structures cannot be the same project as deciding how we ought to live our lives, which takes place from the practical perspective. So Kant was highly critical of theorists who attempted to draw moral conclusions from contingent facts about the human mind and its circumstances. Instead, he thought, we must pursue "a pure moral philosophy which is fully cleansed of everything that might be in any way empirical and belong to anthropology. ${ }^{5}$ Many contemporary philosophers follow Kant here, arguing that psychological approaches simply confuse the practical point of moral inquiry. So, writes Thomas Nagel, "The pursuit of objective practical principles is not to be conceived of as a psychological exploration of our moral sense, but as an employment of it." ${ }^{\prime 6}$

\section{II.2 Reply: Reflective Agency and Self-Understanding}

It seems to me that we should concede the core of Kant's criticism: there is something distinctive about conceiving of ourselves as moral agents, and this does not sit well alongside a psychological self-conception. But, unless we adopt a very radical sort of

\footnotetext{
${ }^{4}$ The clearest statement of Kant's view on this point comes in Book 3 of his Groundwork for the Metaphysics of Morals (Kant 1785). Interpreting Kant is always a delicate matter, and I do not have the space to fully explicate the interpretation given in the text. Here I mostly follow Korsgaard (1996a), but see also my (Rini, manuscript) for details.

${ }^{5}$ Kant (1785), $A k$ 4:389. Kant is quite strident on this point; he goes on to insist that an empirical approach to fundamental moral principles gives only a "base way of thinking", "disadvantageous to the purity of moral themselves... a bastard patched together from limbs of quite diverse ancestry" (4:425-426).

${ }^{6}$ (Nagel 1986: 150-151). See also (Nagel 1978) and (Fried 1978).
} 
metaphysics, it seems we must still admit that, in the end, we are subject to the laws of nature, including psychological laws. Kant needn't deny this: his point is simply that there is a problem in simultaneously thinking in this way and thinking of ourselves from the practical perspective. ${ }^{7}$ The two perspectives, practical and psychological, cannot be entered into at the same time.

This is not a particularly satisfying conclusion. It makes the practical perspective look a bit like a petulant child: covering her eyes, plugging her ears, and refusing to acknowledge the presence of the laws of nature all around her. And it makes the psychological perspective sound myopic and sterile, divorced from the things we actually care about in life. The problem here comes from Kant's refusal to engage with contingent, empirical facts about human nature: he insists upon seeing a moral agent strictly as a rational agent, with no other attributes. Could we dispense with this aspect of Kant's approach, permitting consideration of some contingent elements of our nature, without abandoning the essential point of the practical perspective?

A very appealing approach emphasizes that we are reflective entities. Unlike mechanical devices or simple animals, we can think about the motives of our thoughts and actions, and it is essential to our nature that we have the ability to reflectively endorse or refrain from endorsing these motives (Frankfurt 1971). Christine Korsgaard, in developing her contemporary Kantianism, has taken a leading role in highlighting the role of reflection in moral agency. Korsgaard offers what she calls the transparency requirement on normative ethics:

"A normative moral theory must be one that allows us to act in the full light of knowledge of what morality is and why we are susceptible to its influences, and at the same time to believe that our actions are justified and make sense." ${ }^{8}$

The reflective perspective, unlike Kant's practical perspective, is not incompatible with acknowledging contingent facts about our nature. It need only insist that our focus must be on evaluating these natural facts, rather than merely describing them. Understood this way, the reflective perspective does not at all reject the relevance of empirical psychology to normative ethics. In fact, I suggest, it supports an argument requiring psychological inquiry:

\section{The Self-Understanding Argument}

(1) Being moral agents requires that we understand and endorse the motives of our judgments and actions.

\footnotetext{
${ }^{7}$ Kant often certainly sounds as if he is making a metaphysical claim, where adopting the practical perspective entails denying that the world really contains deterministic natural laws. But this is not the only interpretation available. See Korsgaard (1996).

${ }^{8}$ (Korsgaard 1996b: 17). For a related discussion specifically regarding psychological findings, see (Kamm 2009 : 469).
} 
(2) Many of the motives of our judgments and actions can only be fully understand in light of findings from empirical moral psychology.

(3) Therefore, in order to be effective moral agents we must pay attention to discoveries of empirical moral psychology.

I take it that step (1) is granted by anyone who prefers the gentler reflective perspective over Kant's mysterious practical perspective. ${ }^{9}$ Step (2) is best shown through example.

\section{II.3 Examples: Human Nature and Normative Ethics}

If we want evidence for how empirical psychology might aid in reflective selfunderstanding, it could help to look away from Kant for awhile. Another deep tradition in moral theory sees morality as a natural phenomenon, growing out of basic facts about the biological constitution of human beings and their relations to one another. Owen Flanagan (1996) traces this tradition from Aristotle through John Dewey, and argues that informing moral philosophy through contemporary psychology is another, necessary iteration. ${ }^{10}$ The traditional Aristotelian approach assumed that there is an ultimate telos, or purpose, to human nature, that the essence of being human is aiming at a state of perfected humanness. We needn't take teleology on board to adopt this sort of view. The key point is simply that understanding how we ought to live our lives begins with understanding what sorts of creatures we are, in our capacity as rational agents and as contingent, limited organisms. When we attend to empirical discoveries, we may find grounds for re-evaluating tenets of normative theory.

Start, for instance, with biology. The primatologist Frans de Waal argues that social contract theory (the sort advocated by Hobbes and Rawls) assumes that the construction of complex social arrangements is needed to mitigate the effects of individual self-interest. However, de Waal claims, careful study of primate behaviour and the evolutionary origin of the human species would instead lead to the conclusion that we are predisposed to social cooperation; we are "obligatorily gregarious" (de Waal 2006: 4). If this is recognized, then one of the central puzzles of moral inquiry becomes inverted: instead of trying to explain why we ever cooperate, we should instead focus on understanding why we sometimes fail to do so. ${ }^{11}$ This explanatory inversion does not eliminate the need to reflectively evaluate

\footnotetext{
${ }^{9}$ Although objections to step (1) are possible. One might challenge the idea of agency itself, or at least the idea that reflective endorsement is a necessity for it. Doris (2009) makes an argument of this sort. Alternately, one might suggest that the connection between steps (1) and (2) is less clear than I make it seem. See (van Roojen 1999) for an argument that the kinds of reasons relevant to moral agency do not map onto the kinds of motives discussed in psychological theory.

${ }^{10}$ Other philosophers sympathetic to a human-nature based ethics include Foot (1995) and Kitcher (2011).

${ }^{11}$ For other examples of how evolutionary psychology might alter speculatively empirical claims in moral theory, see (Petrinovich, O’Neill, \& Jorgensen 1993) and (Sripada 2005).
} 
our altruistic practices, but it does suggest that a there is far less distance between our natures and our norms than many had assumed.

Now consider social interaction. Gossip is often thought of as morally extraneous: idle chatter aimed purely at titillation, rather than at seriously evaluating the ethicality of particular actions. But according to (Sabini \& Silver 1982: 101), who argue partly on evidence from social psychology, gossip in fact fulfils an essential role in moral practice. Gossip, they say, functions to coordinate social norms, and does so in a way permitting far greater detail and nuance than what is possible in formal moral instruction or debate. If this is right, we might wish to reevalute how we regard gossipers. And, more importantly, normative ethics might benefit from examining moral commitments disclosed through informal gossip, alongside more traditional moral intuitions. ${ }^{12}$

Two important and ambitious research programs provide wide-ranging treatments of our psychological moral nature. One is the developmental tradition pioneered by Jean Piaget, and extended by Lawrence Kohlberg. ${ }^{13}$ According to this account, human moral judgment arises from an invariant sequence of developmental stages, each consisting of logical improvements upon the limitations of prior stages. Kohlberg regards this account as capturing the essence of the moral domain so completely that, he says, "an adequate psychological analysis of the structure of a moral judgment, and an adequate normative analysis of the judgment will be made in similar terms." ${ }^{14}$

A second, more recent, research program concerns the interpretation of moral intuitions. Reflective equilibrium, the dominant method of contemporary normative ethics, involves soliciting intuitive reactions to test cases, which are systematized in search of latent principles. The method is most fully articulated in the work of John Rawls $(1951,1971)$, where it is primarily presented as a means of justifying moral principles. But Rawls himself noted a resemblance to the descriptive enterprise of linguistic psychology (Rawls 1971: 47). A number of authors (Mikhail 2011; Dwyer 2006; Hauser 2006) have pressed this linguistic analogy, arguing that moral intuitions result from a domain-specific, partly innate cognitive mechanism, by which our minds map the causal structure of observed situations onto morally valenced reactions. The suggestion is that, if reflective equilibrium has an aim of

\footnotetext{
${ }^{12}$ Similar comments apply to the phenomenon of moral disagreement. Knowing how and why we come to hold diverging moral views - between various communities (Moody-Adams 2002; Haidt 2012) or even within individual minds (Cushman \& Young 2009) - might provide clues as to how to deal with them.

${ }^{13}$ Piaget, in fact, aims his work squarely at addressing Kant's challenge to empirical psychology. Piaget's developmental account is explicitly intended to reveal the nature of moral agency (or autonomy). I discuss this argument at length, and consider its implications for normative ethics, in (Rini, manuscript).

${ }^{14}$ (Kohlberg 1971: 224). For a critical appraisal of Kohlberg's normative claims, see (Goodpaster 1982). Kohlberg's findings have also been criticized on empirical grounds, especially by his former collaborators (Gilligan 1982) and (Turiel 1983). For more recent work in the developmental tradition, see (Rest, Narvaez, Bebeau, \& Thoma 1999) and (Narvaez \& Lapsley 2009).
} 
finding the underlying structure of our moral intuitions, then surely the powerful empirical techniques of psychology can be an aid to purely introspective theorizing. ${ }^{15}$

All of these examples are susceptible to empirical challenge, and certainly not everyone is persuaded by each. But the overall point should be clear: to the extent that reflective self-understanding plays a central role in normative ethics, empirical psychology enhances rather than detracts from this role. The claim is not that descriptive psychological findings lead immediately to substantive normative conclusions. Rather, the claim is that a reflective approach to normative ethics unnecessarily hobbles itself if it refuses to engage with this powerful form of self-understanding.

\section{Which actions are morally permitted or required?}

\section{III.1 Challenge: The Is-Ought Gap}

In his Treatise of Human Nature, David Hume famously expressed surprise at finding other authors moving from claims about what is the case to claims about what ought to be the case. According to Hume, it "seems altogether inconceivable, how this new relation ['ought'] can be a deduction from others, which are entirely different from it." ${ }^{16}$ Hume here articulated the is-ought gap: the doctrine that descriptive claims (about how matters actually are) constitute a logically different sort than prescriptive claims (about how matters should be), and therefore that something goes wrong when we attempt to generate prescriptive claims from purely descriptive ones.

The is-ought gap is related to a central aim of moral philosophy: identifying which actions ought to be pursued. For Hume, the gap stemmed from the idea that moral claims are intrinsically motivational in a way that descriptive claims are not. During the twentieth century the is-ought gap was frequently formulated as a point about moral language. ${ }^{17}$ According to a particularly influential mid-century view, moral vocabulary has an imperative logic, even when its surface grammar appears descriptive. For instance: 'you have an obligation to help the needy' appears to describe a fact about you (your having a thing, an obligation), but it is actually logically similar to the command, 'you, go help the needy'. If

\footnotetext{
${ }^{15}$ The linguistic analogy has been criticized both for its normative claims (Daniels 1980) and its empirical grounding (Dupoux \& Jacob 2007; Prinz, 2008). For general discussions of descriptive interpretations of reflective equilibrium, see (Scanlon 2002) opposed, and my own (Rini 2011, chapter 3), in favor. A closely related research program, focused on describing the causal role of intention-ascription in moral judgment, provides a detailed example of what careful empirical work can uncover (Knobe 2003; Young \& Saxe 2008; Cushman 2008).

${ }_{16}$ (Hume 1739) Book III, section 1, part 1.

17 This 'linguistic turn' owes a great deal to Moore (1903). For helpful interpretation of both Hume and Moore on is/ought questions, see (Mackie 1977: 64-73) and (Joyce 2006: 146-156).
} 
this view is correct, then it is a misuse of language to suggest that moral claims follow from factual claims in any logical sense. ${ }^{18}$ Imperatives do not logically follow from declaratives.

Whatever its grounding, the is-ought gap has an intuitive plausibility. The question of what we should do, of what sorts of actions we should engage in, is simply not answered by a purely descriptive characterization of our existing tendencies to engage in or avoid particular actions - and these are precisely the sorts of things studied by empirical moral psychology. There is, then, at least a prima facie burden to explain how psychological inquiry can produce any conclusions relevant to 'ought' considerations.

\section{III.2 Reply: Ought Implies Can}

Alongside the is-ought gap sits another venerable philosophical dictum: 'ought implies can'. It does not make sense to claim that one 'ought' to do something unless it is possible for the person to do so. ${ }^{19}$ For instance: it is nonsense to insist that you, personally, ought to stop a dangerous meteor from striking the Earth, because individual people simply do not have this ability. If moral theory aims at providing guidance to actual ethical decisions, then it must respect the limitations of actual human ability.

Applications of 'ought' implies 'can' are fairly obvious in cases of temporal or physical impossibility. The present argument aims to draw attention to less obvious cases of psychological impossibility. Our minds are limited in various ways, and a genuinely actionguiding normative ethics should be attentive to these limitations. This is the kernel of Owen Flanagan's Principle of Minimal Psychological Realism:

Make sure when constructing a moral theory or projecting a moral ideal that the character, decision processing, and behavior prescribed are possible, or are perceived to be possible, for creatures like us. ${ }^{20}$

If we accept this Principle, then clearly empirical moral psychology will be essential to the aims of moral philosophy. Our best clues about our psychological limitations will surely come from empirical inquiry. Moral theory constructed in ignorance of these limitations will issue frustratingly unfulfillable prescriptions.

It is worth distinguishing two ways in which we could be psychologically incapable of meeting some particular moral prescription. The first way is cognitive: the prescription requires us to make decisions that involve resources of calculation, memory, or imagination which we do not possess. Consequentialist moral theorists have long been challenged to explain how it could be possible for actual agents to recognize, let alone calculate, the

\footnotetext{
${ }^{18}$ For examples of the linguistic formulation of the is-ought gap, see (Stevenson 1944: 271-276) and (Hare 1952: 17-55). Williams (1985: 121-131) argues that the linguistic formulation does not clarify matters.

${ }^{19}$ Though see (Graham 2011) for a recent opposed view.

${ }^{20}$ (Flanagan 1993: 32). See also a related argument in (Appiah 2008: 22-23).
} 
mushrooming consequences of their individual actions, to which they have developed complex responses (Sidgwick 1907; Hooker 1990). But there may be more subtle cognitive limitations on our moral thinking. For instance, Horgan and Timmons (2009) argue that the "frame problem" from cognitive science - concerning the difficulty of providing a discrete specification for the domain of any particular decision - shows that our moral psychology cannot consist solely in a set of general, exceptionless rules, and therefore any moral theory that does consist in such rules violates the 'ought'/'can' stricture. ${ }^{21}$

The second way we may be psychologically limited concerns our motivations. It may be that we have strong, persistent motivations to behave or refrain from behaving in particular ways. A moral theory that requires us to do things we cannot feel motivated to do is not much use for action-guidance. Petrinovich and O'Neill (1993; 1996)) argue that evolutionary psychology can uncover "biological universals" among human motivations, which are likely to be strict limitations, given their hard-wiring in our adaptive history. Psychological limitations can also play a role in evaluation of social practices. So, writes John Rawls: "It is... a consideration against a conception of justice that in view of the laws of moral psychology, men would not acquire a desire to act upon it even when the institutions of their society satisfied it. For in this case there would be difficulty in securing the stability of social cooperation."22

A strong objection can be raised against the argument from psychological possibility, especially in its motivational form: often, when we claim that some act is not psychologically possible for us, we are merely using psychology to invent excuses for not honouring difficult or unpleasant moral duties. Without question, this is a concern that we ought to address for any particular application of this argument. But then it really will come down to the empirical details, to determine just how malleable our cognitive or motivational capacities are (Schleim \& Schirmann 2011). So this point is best understood as a cautionary note rather than a direct objection to the argument. ${ }^{23}$

\section{III.3 Examples: Virtue and Psychological Limitations}

Interestingly, the argument from psychological possibility is illustrated on both opposing sides of an ongoing debate over the relationship between cognitive science and virtue ethics. Virtue ethics is a substantive normative theory, due in large measure to

\footnotetext{
${ }^{21}$ See also (Gigerenzer 2008: 6) and (Moody-Adams 2002: 140) for other applications of 'ought'/'can' to limitations on cognitive or imaginative human capacities.

22 (Rawls 1971: 138). Rawls continued to draw attention to this role for psychological findings in his later work (Rawls 1974: 294; 1987: 24). Rawls' attention to psychological realism has brought his method criticism as overly conservative, but an ought-implies-can argument like the one sketched in this section may actually show this sort of conservatism to be a theoretical virtue. See my (Rini 2011, chapter 3).

${ }^{23}$ Even Peter Singer, usually quite uncompromising about the demandingness of morality, allows moral theory to bend for certain psychological limitations. For instance, Singer notes that partiality toward family runs contrary to impersonal consequentialist theory. However, he says, familial partiality is so biologically entrenched that it is better to harness it - and so secure reliable concern for local welfare - than to attempt to fight it. See (Singer 1981: 33-36).
} 
Aristotle, which understands morally correct actions and motivations as those possessed by a person with good moral character. Virtues are stable dispositions of character, inclining one to engage in appropriate actions across a range of circumstances. Virtue ethics has experienced a recent revival, especially in the views of those who see it as a providing a richer conception of moral life than offered by other theories (Anscombe 1958; Maclntyre 1981; Hursthouse 2002).

One research program claims that central findings from cognitive science "are more consilient with the assumptions of virtue theory than with other theories." ${ }^{24}$ While this position is partly supported by positive arguments - from affective neuroscience and the predictions of connectionist neural modelling - one of its central premises is an oughtimplies-can argument against rival theories. According to Paul Churchland, consequentialist and deontological normative theories "surreptitiously presuppose a background theory about the nature of cognition, a theory that we now have overwhelming reason to believe is empirically false." ${ }^{25}$ The idea is that cognition in general, and so moral cognition in particular, cannot be partitioned into discrete belief-states with unique logical conditions. Since living according to other normative theories would require that sort of psychology (at least according to proponents of the argument) those theories are disqualified on oughtimplies-can grounds. Virtue ethics, by contrast, is held to be the only normative theory compatible with the purported facts about cognition.

A quite different research program suggests the opposite: evidence from cognitive science undermines the tenability of virtue ethics as a normative theory. Robust findings in social psychology, drawn together under the heading of Situationism, suggest that most human behaviour is explained not by persistent character traits, but by automatic responses to narrow situational factors. ${ }^{26}$ If this is so, then people simply do not have general character traits - such as courage or fidelity - in the way virtue ethics requires (Doris 2002; Harman 1999). ${ }^{27}$ If it is not possible for people to possess the relevant sort of character traits, then a normative theory evaluating them on that basis cannot be of much use.

Debate over the status of virtue ethics continues, with contributions from psychologists and philosophers alike. However these arguments ultimately resolve, it is instructive to note the implied agreement among their participants, that moral theory must be responsive to the limitations on human agency revealed by psychological inquiry.

\footnotetext{
${ }^{24}$ (Casebeer \& Churchland 2003: 173). See also (Clark 1996) and (Churchland 2011).

25 (Churchland 2000: 294). This negative argument is related, but not identical, to Horgan and Timmons' (2009) frame problem, discussed above. For further related arguments, see (Stich 1993) and (Johnson 1996).

${ }^{26}$ Foundational studies in this literature include (Darley \& Batson 1973), (Milgram 1973), and (Haney, Banks, \& Zimbardo 1973). For an overview, see (Ross \& Nisbett 1991)).

${ }^{27}$ For criticism of this application of the Situationist argument, see (Kamtekar 2004), (Annas 2005), and (Sabini \& Silver 2005).
} 


\section{Which of our moral beliefs are justified?}

\section{IV.1 Challenge: Justification and Explanation}

A final central aim of normative ethics is epistemic: we aim to determine which of our moral beliefs (about actions or states of affairs) are justified. We presume that some of our existing moral beliefs are not justified; we aim to sort out which these are, and to eliminate them from our normative theories. One way we do this, in reflective equilibrium, involves reflective consideration of moral intuitions solicited by relevant test cases. Those beliefs which best unify intuitions surviving reflective scrutiny are the ones we take to be justified. The others get discarded, and a complete moral theory is constructed only from justified beliefs.

In contrast, a project of simply describing our present beliefs cannot be responsive to the question, as it would not discriminate between justified and unjustified beliefs. So it is unclear how empirical moral psychology could have any relevance here, since it is just such a descriptive enterprise. More particularly, empirical psychology aims at explaining the causal structure of our beliefs. But, as many philosophers have noted, explaining a belief and justifying a belief are logically separate pursuits. From a first-person perspective, that of the person who 'owns' the moral belief, an explanation of its causal structure has no obvious bearing on the matter of whether one ought to go one believing it. Writing in this vein, Ronald Dworkin asks us to imagine that new discoveries show some of our beliefs about justice to be secretly motivated by concerns of self-interest:

It will be said that it is unreasonable for you still to think that justice requires anything, one way or the other. But why is that unreasonable? Your opinion is one about justice, not about your own psychological processes... You lack a normative connection between the bleak psychology and any conclusion about justice, or any other conclusion about how you should vote or act. ${ }^{28}$

As Dworkin's example suggests, psychological findings cannot themselves tell us which of our moral beliefs are justified, because such findings are not about the content of moral beliefs. An explanatory inquiry has a different subject matter than a justificatory inquiry.

\section{IV.2 Reply: The Conditions of Moral Judgment}

Immediately following the quotation above, Dworkin concedes that the "bleak psychology" might lead you to rethink your moral beliefs, if you added a normative premise stepping from the factual claim to a normative conclusion. For instance, you might decide that aims pursued from covert self-interest are morally unacceptable. Indeed, once such normative premises are included, explanations for beliefs are readily conceded to

\footnotetext{
${ }^{28}$ (Dworkin 1996: 124-125). See also (Strawson 1974: 25), and (Nagel 1997: 105).
} 
undermine apparent justifications; philosophers have a notion of "explaining away" intuitively-grounded beliefs for precisely this purpose.

In fact, established methodology in normative ethics allows that moral intuitions can sometimes be disqualified on grounds of their originating conditions. We sometimes reject an intuition not because of its content (i.e. that some action is right or wrong), but because the thinking that led to the intuition occurred in some concrete situation which we regard as unlikely to generate credible intuitions. So, for instance, we do not trust intuitions originating when we are distracted, tired, intoxicated, etc. Self-interest, indeed, may be another such condition: we think we do well not to trust moral intuitions formed while we are primed to worry about our own stake in some matter. ${ }^{29}$

Notice that the practice of excluding intuitions on grounds of originating conditions does not challenge Dworkin's claim. In these cases we must still have a normative premise perhaps implicit - that intuitions formed under conditions of intoxication or self-interest are unreliable intuitions, intuitions that cannot convey justification to any belief or theory constructed from them. ${ }^{30}$ Excluding intuitions requires stepping beyond an explanatory project and into a justificatory one.

I think that proponents of empirical moral psychology should concede all of this, because it shows their program to be simply an extension of existing philosophical methodology. Since it is already accepted that originating conditions are sometimes grounds for disqualifying intuitions, there should be no principled objection to similar arguments employing psychological premises - provided these arguments also include satisfactory normative premises.

What psychology uniquely offers is an enhanced understanding of the nature of originating conditions. Sometimes it is easy to notice that certain particular intuitions have occurred under conditions of intoxication or self-interest; we can know this through direct self-observation. But other times, facts about the conditions in which our intuitions originate are less obvious to us, such as when we do not realize we are primed for selfinterest, or even when we do not recognize the intoxicating influence of some drug or environmental cue. The observational and correlational powers of empirical psychology are likely to be far better at tracking such originating conditions. More importantly, psychology may allow us to come to recognize new categories of disqualifying originating conditions, by exposing the causal relations embedded within them.

\footnotetext{
${ }^{29}$ Rawls stresses that his method of reflective equilibrium is meant to operate only upon "considered moral judgments", which are a class of intuitions rendered according to constraints like these. See (Rawls 1951: 179) and (Rawls 1971: 47-48).

${ }^{30}$ There is a difficult issue here about what type of norm plays this role: intoxicated intuitions might be excluded on epistemic grounds (intoxication being though not conducive to truth in any domain), while the self-interest exclusion may represent a distinctively moral norm. But we can set aside such issues here.
} 


\section{IV.3 Examples: Psychological Originating Conditions}

Originating condition arguments are among the most commonly used by contemporary empirically-informed normative ethicists. The examples I discuss in this section are intended to be illustrative of the style of argument, and this is certainly not an exhaustive survey.

For a first example: many recent studies appear to show that our moral intuitions are highly sensitive to emotional manipulation, via environmental cues like physical cleanliness or emotional levity (Schnall, et al. 2008; Valdesolo \& DeSteno 2006). ${ }^{31} \mathrm{Haidt}$ (2001; Haidt \& Bjorklund 2008) suggests that these correlations show virtually all moral thinking to be "rationalization" rather than genuine reasoning. ${ }^{32}$ Greene (2008) makes a more selective argument, claiming that deontological intuitions in particular are shown by neuroscience to be correlated to an unreliable sort of emotional processing. ${ }^{33}$ Both of these arguments rely on the normative premise that emotional influence undermines the justificatory status of a moral intuition, something we might very well dispute. ${ }^{34}$ For the moment, the point is only this: Haidt and Greene have used psychology to identify the influence of emotion where we might not have suspected it, so if we do agree that emotional influence is a disqualifying originating condition, then we ought to pay close attention.

Another argument of this sort works slightly differently. Rather than tying intuitions to emotion, this argument instead aims to extract the computational rules guiding our intuitions. The substantial literature on moral heuristics is central here. According to this literature, moral judgment is like judgment in other domains: many of our intuitions result from the rapid, unconscious application of decision rules. These rules are usually reliable within their target domains, but under certain circumstances they produce systematic errors. ${ }^{35}$ Importantly, the conditions under which these errors arise are often extremely subtle, likely to be detected only by psychological techniques, rather than introspective self-

\footnotetext{
${ }^{31}$ See also (Wheatley \& Haidt 2005; Schnall et al. 2008; Eskine et al. 2011; Strohminger et al. 2011) for other relevant empirical findings.

32 It should be noted that in Haidt's later work (Haidt 2012) he downplays the centrality of emotion and instead focuses on automated cognition. For critical discussion of Haidt's view, see (Pizarro \& Bloom 2003; Kennett \& Fine 2009; Liao 2011; Huebner 2011) among others.

${ }^{33}$ See Greene (Greene et al. 2001; Greene et al. 2004) for the psychological background. For further discussion, see (Singer 2005; Nichols \& Mallon 2006; Allman \& Woodward 2008; Kamm 2009; Kahane \& Shackel 2010; Kumar \& Campbell 2012). Berker (2009) offers a particularly comprehensive criticism of the empirical and normative aspects of Greene's argument.

${ }^{34}$ See (Sherman 1990; Nussbaum 2003: 354-364; Nichols 2004; Narvaez 2010) for more positive consideration of the role of emotion in moral inquiry.

${ }^{35}$ For more on moral heuristics, see (Baron 1994; Horowitz 1998; van Roojen 1999; Kamm 1998; Sunstein 2005; Gigerenzer 2008; Appiah 2008). Sinnott-Armstrong (2008) makes a related, and still more ambitious argument, claiming that the influence of morally irrelevant factors like framing effects or presentational order are so pervasive as to cast an epistemic shadow over all moral intuitions. This sort of argument is not unique to the moral domain - see (Weinberg 2007; Alexander 2012, chapter 4) for related criticism of the role of intuition in all areas of philosophy.
} 
monitoring. Of course, the claim that certain applications of the rules count as errors is a normative premise, not provided by psychology itself. But, again, psychology's contribution to this argument is irreplaceable; the re-evaluations urged by the argument could not have occurred without empirical discoveries. ${ }^{36}$

All that said, it is worth drawing a cautionary line around these arguments. Their proponents often have stridently ambitious aims, attempting to undermine or displace longestablished moral theories. Sometimes these revisionary ambitions appear to get the better of their authors, leading to minimization of the role of normative theory itself in their arguments. For example: Horowitz (1998: 381) and Greene (2008: 70) each spend a good deal of time demonstrating the psychological correlates of particular intuitions, then rather hastily assert that the correlated factors are "nonmoral" or "morally irrelevant", with little to no justification for these assertions. Many readers go away unconvinced. But the argument of this section does not depend on the specifics of any of these examples - they are meant simply to illustrate the form of originating conditions arguments. Certainly more work needs to be done on the normative premises of these arguments - but the logic itself seems clear. ${ }^{37}$

\section{Conclusion}

In this chapter I have identified three central aims of normative ethics, shown how each aim might seem to suggest strong limitations on the relevance of empirical moral psychology, then argued that in fact each aim actually supports an important role for psychological inquiry. Each of these discussions thus constitutes an independent argument for sustaining and expanding normative ethicists' engagement with empirical findings.

But these disciplinary interactions are at quite early stages. The arguments discussed above only hint at the rich range of questions still to be investigated. Will new psychological discoveries prove more difficult to accommodate to reflective, practical agency? If our psychology imposes limits on what morality can demand of us, should we try to change our psychology? How pervasive are undermining originating conditions - will recognizing their extent risk general moral scepticism? We do not have answers to these questions. We do

\footnotetext{
${ }^{36}$ Many responses to the moral heuristics argument and Greene's argument, including most of those mentioned in footnotes above, involve challenging their particular empirical or normative premises. Another response, suggested by Levy (2006), claims that a constructivist metaethic can immunize us to many of these challenges. If we hold that morality simply is whatever our intuitions (or some suitably restricted class of them) correspond to, then there is little danger of our intuitions turning out driven by "morally irrelevant" factors the psychological findings will simply tell us what our moral beliefs have been committed to all along.

${ }^{37}$ I discuss this issue at greater length in (Rini 2011), where I also provide a broader theoretical framework for arguments of this sort. Similar moderate approaches - sympathetic to empirical investigation, but issuing cautionary qualifications - can be found in (Stevenson 1944: 123; Baier 1985: 224; Noble 1989: 53; Held 1996: 83; Appiah 2008; Tiberius 2010; Kahane forthcoming). But see (Machery 2010) for a sceptical argument, accusing the moderate approach of circularity.
} 
not yet even know precisely how to ask these questions in a way that they might be answered. Philosophers and psychologists have a lot of work to do together. ${ }^{38}$

\section{Citations}

Alexander, J. (2012). Experimental Philosophy: An Introduction. Polity.

Allman, J., \& Woodward, J. (2008). What are Moral Intuitions and Why Should we Care about Them? A neurobiological perspective. Philosophical Issues, 18(1), 164-185.

Annas, J. (2005). Comments on John Doris's 'Lack of Character'. Philosophy and Phenomenological Research, 71(3), 636-642.

Anscombe, G. E. M. (1958). Modern Moral Philosophy. Philosophy, 33(124), 1-19.

Appiah, K. A. (2008). Experiments in Ethics. Harvard University Press.

Baier, A. (1985). Theory and Reflective Practices. In Postures of the Mind. Minneapolis: Univ Of Minnesota Press.

Baron, J. (1994). Nonconsequentialist decisions. Behavioral and Brain Sciences, 17(01), 1-10.

Berker, S. (2009). The Normative Insignificance of Neuroscience. Philosophy \& Public Affairs, 37(4), 293-329.

Casebeer, W. D., \& Churchland, P. S. (2003). The Neural Mechanisms of Moral Cognition: A MultipleAspect Approach to Moral Judgment and Decision-Making. Biology and Philosophy, 18(1), 169-194.

Churchland, P. (2000). Rules, Know-How, and the Future of Moral Cognition. Canadian Journal of Philosophy, 30(Supplement), 291-306.

Churchland, P. S. (2011). Braintrust: What Neuroscience Tells Us about Morality. Princeton University Press.

Clark, A. (1996). Connectionism, Moral Cognition, and Collaborative Problem Solving. In L. May, M. Friedman, \& A. Clark (Eds.), Minds and Morals: Essays on Cognitive Science and Ethics (pp. 109-127). Cambridge, MA: MIT Press.

Cushman, F. (2008). Crime and punishment: Distinguishing the roles of causal and intentional analyses in moral judgment. Cognition, 108(2), 353-380.

Cushman, F., \& Young, L. (2009). The Psychology of Dilemmas and the Philosophy of Morality. Ethical Theory and Moral Practice, 12, 9-24.

Daniels, N. (1980). On some methods of ethics and linguistics. Philosophical Studies, 37(1), 21-36.

Darley, J. M., \& Batson, C. D. (1973). 'From Jerusalem to Jericho': A study of Situational and Dispositional Variables in Helping Behavior. Journal of Personality and Social Psychology, 27, 100-108.

De Waal, F. (2006). Primates and Philosophers: How Morality Evolved. Princeton: Princeton University Press.

Doris, J. M. (2002). Lack of Character: Personality and Moral Behavior. Cambridge University Press. Doris, J. M. (2009). Skepticism about Persons. Philosophical Issues, 19(1), 57-91.

\footnotetext{
${ }^{38}$ The contents of this chapter benefited significantly from discussions with Tommaso Bruni, Nora Heinzelmann, Guy Kahane, and Felix Schirmann, and from written comments by Stephan Schleim and an anonymous referee. This research was part of the project 'Intuition and Emotion in Moral Decision Making', funded by the VolkswagenStiftung's European Platform for Life Sciences, Mind Sciences, and the Humanities (grant II/85 063).
} 
Doris, J. M., \& Stich, S. (2007). As a Matter of Fact: Empirical Perspectives on Ethics. In F. Jackson \& M. Smith (Eds.), The Oxford Handbook of Contemporary Philosophy (1st ed., Vol. 1, pp. 114153). Oxford: Oxford University Press.

Dupoux, E., \& Jacob, P. (2007). Universal moral grammar: a critical appraisal. Trends in Cognitive Sciences, 11(9), 373-378.

Dworkin, R. (1996). Objectivity and Truth: You'd Better Believe it. Philosophy \& Public Affairs, 25(2), 87-139.

Dwyer, S. (2006). How Good is the Linguistic Analogy? In P. Carruthers, S. Laurence, \& S. Stich (Eds.), The Innate Mind: Culture and Cognition. Oxford: Oxford University Press.

Eskine, K. J., Kacinik, N. A., \& Prinz, J. J. (2011). A bad taste in the mouth: gustatory disgust influences moral judgment. Psychological science, 22(3), 295-299.

Flanagan, O. (1993). Varieties of Moral Personality: Ethics and Psychological Realism. Cambridge, MA: Harvard University Press.

Flanagan, O. (1996). Ethics Naturalized: Ethics as Human Ecology. In L. May, M. Friedman, \& A. Clark (Eds.), Minds and Morals: Essays on Cognitive Science and Ethics (pp. 19-43). Cambridge, MA: MIT Press.

Foot, P. (1995). Does Moral Subjectivism Rest on a Mistake? Oxford Journal of Legal Studies, 15(1), $1-14$.

Frankfurt, H. G. (1971). Freedom of the Will and the Concept of a Person. Journal of Philosophy, 68(1), 5-20.

Fried, C. (1978). Biology and Ethics: Normative Implications. In Morality as a Biological Phenomenon: The Presuppositions of Sociobiological Research (pp. 187-197). Berkeley, CA: University of California Press.

Gigerenzer, G. (2008). Moral Intuition = Fast and Frugal Heuristics? In W. Sinnott-Armstrong (Ed.), Moral Psychology, Vol 2. The Cognitive Science of Morality: Intuition and Diversity (pp. 1-26). Cambridge, MA: MIT Press.

Gilligan, C. (1982). In a Different Voice: Psychology Theory and Women's Development. Cambridge, MA: Harvard University Press.

Goodpaster, K. E. (1982). Kohlbergian Theory: A Philosophical Counterinvitation. Ethics, 92(3), 491498.

Graham, P. A. (2011). 'Ought' and Ability. Philosophical Review, 120(3), 337-382.

Greene, J D, Sommerville, R. B., Nystrom, L. E., Darley, J. M., \& Cohen, J. D. (2001). An fMRI investigation of emotional engagement in moral judgment. Science, 293(5537), 2105-2108.

Greene, Joshua D. (2008). The Secret Joke of Kant's Soul. In W. Sinnott-Armstrong (Ed.), Moral Psychology, Vol. 3. The Neuroscience of Morality: Emotion, Brain Disorders, and Development (pp. 35-80). Cambridge, MA: MIT Press.

Greene, Joshua D., Nystrom, L. E., Engell, A. D., Darley, J. M., \& Cohen, J. D. (2004). The Neural Bases of Cognitive Conflict and Control in Moral Judgment. Neuron, 44(2), 389-400.

Haidt, J. (2001). The emotional dog and its rational tail: a social intuitionist approach to moral judgment. Psychological review, 108(4), 814-834.

Haidt, J. (2012). The Righteous Mind: Why Good People Are Divided by Politics and Religion (1st ed.). New York: Pantheon.

Haidt, J., \& Bjorklund, F. (2008). Social Intuitions Answer Six Questions About Moral Psychology. In W. Sinnott-Armstrong (Ed.), Moral Psychology, Vol 2. The Cognitive Science of Morality: Intuition and Diversity (pp. 181-218). Cambridge, MA: MIT Press. 
Haney, C., Banks, W. C., \& Zimbardo, P. G. (1973). A study of prisoners and guards in a simulated prison. Naval Research Review, 30, 4-17.

Hare, R. M. (1952). The Language of Morals. New York: Oxford University Press.

Harman, G. (1999). Moral Philosophy Meets Social Psychology: Virtue Ethics and the Fundamental Attribution Error. Proceedings of the Aristotelian Society, 99, 315-331.

Hauser, M. D. (2006). The liver and the moral organ. Social Cognitive and Affective Neuroscience, 1(3), 214-220.

Held, V. (1996). Whose Agenda? Ethics versus Cognitive Science. In L. May, M. Friedman, \& A. Clark (Eds.), Minds and Morals: Essays on Cognitive Science and Ethics (pp. 69-88). Cambridge, MA: MIT Press.

Hooker, B. (1990). Rule-Consequentialism. Mind, 99(393), 67-77.

Horgan, T., \& Timmons, M. (2009). What Does the Frame Problem Tell Us About Moral Normativity? Ethical Theory and Moral Practice, 12(1), 25-51.

Horowitz, T. (1998). Philosophical Intuitions and Psychological Theory. Ethics, 108(2), 367-385.

Huebner, B. (2011). Critiquing Empirical Moral Psychology. Philosophy of the Social Sciences, 41(1), 50-83.

Hume, D. (1739). A Treatise of Human Nature. London: Penguin.

Hursthouse, R. (2002). On Virtue Ethics. Oxford University Press.

Johnson, M. L. (1996). How Moral Psychology Changes Moral Theory. In L. May, M. Friedman, \& A. Clark (Eds.), Minds and Morals: Essays on Cognitive Science and Ethics (pp. 45-67). Cambridge, MA: MIT Press.

Joyce, R. (2006). The Evolution of Morality (1st ed.). MIT Press.

Kahane, G. (forthcoming). The armchair and the trolley: an argument for experimental ethics. Philosophical Studies. doi:10.1007/s11098-011-9775-5

Kahane, G., \& Shackel, N. (2010). Methodological Issues in the Neuroscience of Moral Judgement. Mind \& Language, 25(5), 561-582.

Kamm, F. M. (1998). Moral Intuitions, Cognitive Psychology, and the Harming-Versus-Not-Aiding Distinction. Ethics, 108(3), 463-488.

Kamm, F. M. (2009). Neuroscience and Moral Reasoning: A Note on Recent Research. Philosophy \& Public Affairs, 37(4), 330-345.

Kamtekar, R. (2004). Situationism and Virtue Ethics on the Content of Our Character. Ethics, 114(3), 458-491.

Kant, I. (1785). Groundwork for the Metaphysics of Morals. (A. W. Wood, Trans.). New Haven, CT: Yale University Press.

Kennett, J., \& Fine, C. (2009). Will the Real Moral Judgment Please Stand up? The Implications of Social Intuitionist Models of Cognition for Meta-Ethics and Moral Psychology. Ethical Theory and Moral Practice, 12(1), 77-96.

Kitcher, P. (2011). The Ethical Project. Cambridge, MA: Harvard University Press.

Knobe, J. (2003). Intentional action and side effects in ordinary language. Analysis, 63(279), 190-194.

Knobe, J. (2010). Person as scientist, person as moralist. The Behavioral and brain sciences, 33(4), 315-329.

Kohlberg, L. (1971). From 'Is' to 'Ought': How to commit the naturalistic fallacy and get away with it in the study of moral development. In T. Mischel (Ed.), Cognitive Development and Epistemology. New York: Academic Press. 
Korsgaard, C. M. (1996a). Creating the Kingdom of Ends: Reciprocity and responsibility in personal relations. In Creating the Kingdom of Ends (pp. 188-223). Cambridge University Press.

Korsgaard, C. M. (1996b). The Sources of Normativity. Cambridge University Press.

Kumar, V., \& Campbell, R. (2012). On the Normative Significance of Experimental Moral Psychology. Philosophical Psychology, 25(3), 311-330.

Levy, N. (2006). Cognitive Scientific Challenges to Morality. Philosophical Psychology, 19(5), 567-587.

Levy, N. (2009). Empirically Informed Moral Theory: A Sketch of the Landscape. Ethical Theory and Moral Practice, 12(1), 3-8.

Liao, S. M. (2011). Bias and Reasoning: Haidt's Theory of Moral Judgment. In T. Brooks (Ed.), New Waves in Ethics. Palgrave Macmillan.

Machery, E. (2010). The Bleak Implications of Moral Psychology. Neuroethics, 3(3), 223-231.

Maclntyre, A. C. (1981). After Virtue: A Study in Moral Theory. South Bend, IN: Notre Dame Press.

Mackie, J. L. (1977). Ethics: Inventing Right and Wrong. London: Penguin Books.

Mikhail, J. (2011). Elements of Moral Cognition: Rawls' Linguistic Analogy and the Cognitive Science of Moral and Legal Judgment (3rd ed.). Cambridge: Cambridge University Press.

Milgram, S. (1973). Obedience to Authority. New York: Harper Torchbooks.

Moody-Adams, M. (2002). Fieldwork in Familiar Places: Morality, Culture, and Philosophy (New Ed.). Harvard University Press.

Moore, G. E. (1903). Principia Ethica. Cambridge: Cambridge University Press.

Nagel, T. (1978). Ethics as an Autonomous Theoretical Subject. In G. S. Stent (ed.), Morality as a Biological Phenomenon: The Presuppositions of Sociobiological Research (pp. 198-205). Berkeley, CA: University of California Press.

Nagel, T. (1986). The View from Nowhere. New York: Oxford University Press.

Nagel, T. (1997). The Last Word. Oxford: Oxford University Press.

Narvaez, D. (2010). The emotional foundations of high moral intelligence. New directions for child and adolescent development, 2010(129), 77-94.

Narvaez, D., \& Lapsley, D. K. (Eds.). (2009). Personality, Identity, and Character: Explorations in Moral Psychology (1st ed.). Cambridge: Cambridge University Press.

Nichols, S. (2004). Sentimental Rules: On the Natural Foundations of Moral Judgment. Oxford University Press.

Nichols, S., \& Mallon, R. (2006). Moral dilemmas and moral rules. Cognition, 100(3), 530-542.

Nietzsche, F. (1973). The Will to Power: In Science, Nature, Society and Art. (W. Kaufmann, Ed.) (New Ed.). Random House USA Inc.

Noble, C. N. (1989). Normative Ethical Theories. In S. G. Clark \& E. Simpson (Eds.), Anti-Theory in Ethics and Moral Conservatism (pp. 49-64). Albany, NY: SUNY Press.

Nussbaum, M. C. (2003). Upheavals of Thought: The Intelligence of Emotions. Cambridge University Press.

Petrinovich, L., \& O'Neill, P. (1996). Influence of wording and framing effects on moral intuitions. Ethology \& Sociobiology, 17(3), 145-171.

Petrinovich, L., O'Neill, P., \& Jorgensen, M. (1993). An empirical study of moral intuitions: Toward an evolutionary ethics. Journal of Personality and Social Psychology, 64(3), 467-478.

Pizarro, D. A., \& Bloom, P. (2003). The intelligence of the moral intuitions: comment on Haidt (2001). Psychological Review, 110(1), 193-196. 
Prinz, J. J. (2008). Resisting the Linguistic Analogy. In W. Sinnott-Armstrong (Ed.), Moral Psychology, Vol 2. The Cognitive Science of Morality: Intuition and Diversity (pp. 157-170). Cambridge, MA: MIT Press.

Rawls, J. (1951). Outline of a Decision Procedure for Ethics. The Philosophical Review, 60(2), 177197.

Rawls, J. (1971). A Theory of Justice (1st ed.). Cambridge, MA: Harvard University Press.

Rawls, J. (1974). The Independence of Moral Theory. Proceedings and Addresses of the American Philosophical Association, 48, 5-22.

Rawls, J. (1987). The Idea of an Overlapping Consensus. Oxford Journal of Legal Studies, 7(1), 1-25.

Rest, J., Narvaez, D., Bebeau, M. J., \& Thoma, S. (1999). Postconventional Moral Thinking: A NeoKohlbergian Approach. Psychology Press.

Rini, R. A. (2011). Within is the Fountain of Good: Moral Philosophy and the Science of the Nonconscious Mind. New York University, New York.

Rini, R. A. (MS). Kantian Autonomy and Piagetian Autonomy.

Ross, L., \& Nisbett, R. E. (1991). The Person and The Situation (70th ed.). Mcgraw-Hill College.

Sabini, J., \& Silver, M. (1982). Moralities of Everyday Life. New York: Oxford University Press.

Sabini, J., \& Silver, M. (2005). Lack of Character? Situationism Critiqued. Ethics, 115(3), 535-562.

Scanlon, T. M. (2002). Rawls on Justification. In S. Freeman (Ed.), The Cambridge Companion to Rawls (pp. 139-167). Oxford: Oxford University Press.

Schleim, S., \& Schirmann, F. (2011). Philosophical Implications and Multidisciplinary Challenges of Moral Physiology. Trames, 15(2), 127-146.

Schnall, S., Benton, J., \& Harvey, S. (2008). With a clean conscience: cleanliness reduces the severity of moral judgments. Psychological science, 19(12), 1219-1222.

Schnall, S., Haidt, J., Clore, G. L., \& Jordan, A. H. (2008). Disgust as Embodied Moral Judgment. Personality \& social psychology bulletin, 34(8), 1096-1109.

Sherman, N. (1990). The Place of Emotions in Kantian Morality. In O. Flanagan \& A. Rorty (Eds.), Identity, Character and Morality: Essays in Moral Psychology. Cambridge, MA: MIT Press.

Sidgwick, H. (1907). The Methods Of Ethics. Hackett.

Singer, P. (1981). The Expanding Circle: Ethics and Sociobiology. Oxford: Oxford University Press.

Singer, P. (2005). Ethics and Intuitions. Journal of Ethics, 9(3-4), 331-352.

Sinnott-Armstrong, W. (2008). Framing Moral Intuition. In Moral Psychology, Vol 2. The Cognitive Science of Morality: Intuition and Diversity (pp. 47-76). Cambridge, MA: MIT Press.

Sripada, C. S. (2005). Punishment and the strategic structure of moral systems. Biology and Philosophy, 20, 767-789.

Stevenson, C. L. (1944). Ethics and Language. New Haven, CT: Yale University Press.

Stich, S. (1993). Moral Philosophy and Mental Representation. In M. Hechter, L. Nadel, \& R. Michod (Eds.), The Origin of Values (pp. 215-228). New York: Adine de Gruyer.

Strawson, P. F. (1974). Freedom and Resentment. In Freedom and Resentment and Other Essays. Routledge.

Strohminger, N., Lewis, R. L., \& Meyer, D. E. (2011). Divergent effects of different positive emotions on moral judgment. Cognition, 119(2), 295-300.

Sunstein, C. R. (2005). Moral Heuristics. Behavioral and Brain Sciences, 28(4), 531-542.

Tiberius, V. (2010). Appiah and the Autonomy of Ethics. Neuroethics, 3(3), 209-214.

Turiel, E. (1983). The Development of Social Knowledge. Cambridge: Cambridge University Press. 
Valdesolo, P., \& DeSteno, D. (2006). Manipulations of emotional context shape moral judgment. Psychological science, 17(6), 476-477.

Van Roojen, M. (1999). Reflective Moral Equilibrium and Psychological Theory. Ethics, 109(4), 846857.

Weinberg, J. M. (2007). How to Challenge Intuitions Empirically Without Risking Skepticism. Midwest Studies In Philosophy, 31(1), 318-343.

Wheatley, T., \& Haidt, J. (2005). Hypnotic Disgust Makes Moral Judgments More Severe.

Psychological Science, 16(10), 780-784.

Williams, B. (1985). Ethics and the Limits of Philosophy. Cambridge, MA: Harvard University Press.

Young, L., \& Saxe, R. (2008). The neural basis of belief encoding and integration in moral judgment. Neurolmage, 40(4), 1912-1920. 